\title{
Identification of spring viraemia of carp virus (SVCV) by combined RT-PCR and nested PCR
}

\author{
M. Koutná* , T. Veselý, I. Pšikal, J. Hůlová \\ Veterinary Research Institute, Hudcova 70, 62132 Brno, Czech Republic
}

\begin{abstract}
A combination of single-tube reverse transcription (RT)-PCR and nested PCR was used to identify spring viraemia of carp rhabdovirus (SVCV) in infected cell cultures and fish tissues. Two pairs of specific primers (external and internal) were selected from the glycoprotein gene sequence. A specific product of $470 \mathrm{bp}$ was amplified from RNA derived from 34 SVCV isolates including the reference strain (Fijan), using RT-PCR with the external primers. The subsequent PCR using the internal primers yielded a specific product of $141 \mathrm{bp}$ in all cases. No PCR product was obtained following attempts to amplify RNA derived from other fish viruses including pike fry rhabdovirus (PFRV), or from non-infected cells. The identity of the cDNA was confirmed by direct sequencing. PCR sensitivity in the cell-culture system was assessed as about $10^{-1} \mathrm{TCID}_{50} \mathrm{ml}^{-1}$. PCR was further used for the detection of SVCV in 14 clinical samples. Nested PCR allowed us to diagnose the infection in all clinical samples in which SVCV infection was demonstrated by electron microscopy and ELISA. PCR amplification of the SVCV glycoprotein (G) gene is a potential method for rapid diagnosis of spring viraemia of carp; however, it is necessary to verify the method in a higher number of clinical tissue samples. PCR can now be added to current confirmatory diagnostic methods, for determination of SVCV in cell culture. Sequencing of RT-PCR products performed for 7 SVCV isolates (4 Czech, 2 Hungarian, and 1 isolate of unknown origin) revealed a high degree of homogeneity of the G gene region with that of the previously sequenced Fijan strain. The highest nucleotide variability (97.4 to $98.1 \%$ nucleotide similarity) was found between the Hungarian and the other isolates. Knowledge of genetic differences among SVCV isolates will be useful in the development of diagnostic methods and elaboration of vaccination programmes.
\end{abstract}

KEY WORDS: RT-PCR $\cdot \mathrm{SVCV} \cdot \mathrm{Rhabdovirus} \cdot \mathrm{Carp} \cdot$ Sequence analysis

\section{INTRODUCTION}

Spring viraemia of carp virus (SVCV) is a significant pathogenic agent causing considerable economic losses to European and Russian common carp Cyprinus carpio cultures. Less sensitive to infection by SVCV are other cyprinid fish species and the pike Esox lucius. Outbreaks affecting all age groups of fish are observed usually in spring (Wolf 1988). The most effective way of transmitting spring viraemia of carp (SVC) is the transport of live infected fish and contaminated roe. A rapid and reliable method for the identification of SVCV is necessary for the control of the infection.

The bullet-shaped SVCV is classified in the family Rhabdoviridae, genus Vesiculovirus. The SVCV ge- nome, situated in an elongated nucleocapsid surrounded by a lipoprotein layer with glycoprotein projections, is formed by single-stranded negative sense RNA consisting of approximately 11000 bases. Genomic RNA encodes 5 viral proteins including the nucleoprotein, the polymerase-associated phosphoprotein, the membrane protein, the transmembrane envelope glycoprotein $(\mathrm{G})$, and the RNA-dependent RNA polymerase (Roy \& Clewley 1978, Wunner \& Peters 1991, Coll 1995).

The diagnostic methods available so far are based on isolation of the virus in cell cultures and demonstration of the cytopathic effect. The isolate must then be identified by virus neutralisation, immunofluorescence, or ELISA (enzyme-linked immunosorbent assay) (Amos 1985, 
Office International des Epizooties 2000). The whole procedure using any of the 3 tests is laborious and timeconsuming. Admittedly, the immunofluorescence test allowing the identification of SVCV in clinical samples is more rapid; however, fresh tissue-material must be readily available and the interpretation of results is impeded by autofluorescence of fish tissues. Similarly, SVCV can be identified in fish tissues by ELISA within a few hours (Way 1991, Rodák et al. 1993), but the sensitivity of the assay is unsatisfactory and negative results must be confirmed by testing inoculated cell cultures. Another drawback of ELISA is a weak cross-reactivity between SVCV and the antigenically related pike fry rhabdovirus (PFRV) (Jørgensen et al. 1989, Way 1991).

Molecular biological methods employing PCR have recently made a significant advancement in laboratory diagnosis of infectious diseases. PCR allows rapid and accurate demonstration of infectious agents by identification of their nucleic acids. Thanks to a high sensitivity of the reaction, infections by viral agents can be diagnosed, and prophylactic and therapeutic measures can be implemented at initial stages, even before clinical manifestations develop. For these reasons, PCR has become the method of choice for the identification of viral agents for which no cell cultures suitable for isolation are available (Sundsfjørd \& Olsvik 1997, Karunasagar \& Karunasagar 1999).

Reverse transcription PCR (RT-PCR) based on the G gene has been used to differentiate between the rhabdoviruses of viral haemorrhagic septicaemia and infectious haematopoietic necrosis (viruses classified within the genus Novirhabdovirus; Bruchhof et al. 1995, Miller et al. 1998, Strommen \& Stone 1998, Guillou et al. 1999).

Rowley et al. (2001) used primers derived from the G gene of SVCV to obtain nucleotide data from cyprinid rhabdoviruses in which virus neutralisation showed a narrow antigenic similarity to PFRV. SVCV was identified non-specifically using nucleotide analysis of the $G$ gene region.

The objective of our study was to take advantage of the rapid extraction procedure and benefits of PCR to develop a rapid and reliable method for the detection of SVCV in inoculated cell cultures and infected tissue homogenates that distinguishes between the G genes of SVCV and PFRV vesiculoviruses. This paper describes the detection conditions and defines the specificity and semiquantitative sensitivity of PCR.

\section{MATERIALS AND METHODS}

Viruses and cell cultures. The SVCV isolates used in the study are detailed in Table 1 . The isolates were inoculated onto epithelioma papulosum cyprini (EPC) or fathead minnow (FHM) cell lines maintained in
Eagle's minimal essential medium (EMEM) supplemented with $2 \%$ foetal bovine serum and standard concentrations of antibiotics. After $1 \mathrm{~h}$ adsorption, the inoculated cultures were incubated at $15^{\circ} \mathrm{C}$ and cell suspensions were collected for RNA extraction as soon as the cytopathic effect became apparent (usually on Days 4 to 7 post-inoculation).

RNA was also extracted from homogenised kidney, spleen, and heart tissue samples in which the presence of SVCV had been confirmed by electron microscopy and ELISA. The set consisted of 14 tissue homogenates comprising: 6 field samples infected with the Czech Isolates $24,25,30,32,33$, and $34 ; 2$ samples collected from carps experimentally infected with Isolates 24 and 27; and 6 SVCV-free field samples. RNA extracted from non-infected EPC and FHM cells and fish tissues was used as negative controls.

RNA extraction. RNA was extracted from infected cell cultures or tissue homogenates using RNA-affinity spin columns (QIAamp Viral RNA Kit, Qiagen) according to the manufacturer's instructions. Total RNA was extracted from $140 \mu \mathrm{l}$ of the tested material, suspended in $60 \mu \mathrm{l}$ of RNase-free water containing $0.04 \%$ sodium azide, and used in the RT-PCR.

Primers. Specific primers were selected from the nucleotide sequence of the G gene, which shows considerable variation among rhabdovirus species (39.4 to $83.3 \%$ amino acid similarities) (Bjørklund et al. 1996). Two primer pairs (external and internal) were derived from the sequence of the G gene from the Fijan reference strain (Bjørklund et al. 1996, Accession No. U18101), which was the only representative of SVCV sequenced at the time the primers were selected. Melting temperatures and guanine-cytosine contents of forward and reverse primers for each primer pair were identical $\left(64^{\circ} \mathrm{C}\right.$, $45.5 \%$, and $66^{\circ} \mathrm{C}, 50 \%$, for external and internal primers, respectively). Possible homology of the selected oligonucleotides was excluded by checking them with Primer Detective software (Clontech Laboratories, version 1.01). The external primer pair for RT-PCR (sense: 5'-GCC TAA ATG TGT TGA TGG AAC G-3'; antisense: 5'-GGA TAA TAT CGG CTT GGA AAG C-3'), was derived from nucleotides 814 to 835 and 1262 to 1283 of the G gene, respectively. The internal primer pair for nested PCR (sense: 5' -CAA GAG AAG CTG ACA TCA GTG G3'; antisense: 5'-GAC AAT AGG TCC CTC TAC TTC G3'), was derived from nucleotides 944 to 965 and 1063 to 1084 of the G gene, respectively. The sizes of the target regions of amplification by the external and the internal primer pairs were 470 and $141 \mathrm{bp}$, respectively.

Single-tube RT-PCR. Reverse transcription of SVCV RNA and amplification of cDNA were carried out using the Titan One Tube RT-PCR System (Boehringer Mannheim) according to the manufacturer's instructions. The RT-PCR reaction mixture $(50 \mu \mathrm{l})$ contained 
Table 1. Spring viraemia of carp rhabdovirus (SVCV). Isolates used in this study. Year: year of virus isolation; Carp: Cyprinus carpio, goldfish: Carassius auratus, sheatfish: Silurus glanis, grass carp: Ctenopharyngodon idella, silver carp: Hypophthalmichthys molitrix, pike: Esox lucius. nd: no data

\begin{tabular}{|c|c|c|c|c|}
\hline Isolate No. $^{\mathrm{a}}$ & Virus isolate & Year & Host & Country (reference) of virus isolation \\
\hline 1 & Fijan ref. & 1969 & Carp & Croatia( Fijan et al. 1971) \\
\hline 2 & $10 / 6$ & nd & Carp & Germany (Ahne 1986) \\
\hline 3 & 287 & nd & Carp & nd \\
\hline 4 & $65 / 82$ & nd & Carp & nd \\
\hline 5 & 3587 & nd & Goldfish & nd \\
\hline 6 & $12840 / 7$ & nd & Carp & Hungary \\
\hline 7 & $17312 / 5$ & nd & Carp & Hungary \\
\hline 8 & $14286 / 3$ & nd & Sheatfish & Hungary (Fijan et al. 1984) \\
\hline 9 & $17417 / 3$ & 1981 & Sheatfish & Hungary \\
\hline 10 & $17314 / 5$ & nd & Carp & Hungary \\
\hline 11 & 455 & nd & Carp & Germany \\
\hline 12 & 450 & nd & Carp & Germany \\
\hline 13 & 435 & nd & Carp & Germany \\
\hline 14 & ZL4 & 1991 & Carp & Russia \\
\hline 15 & Kp1 & 1984 & Carp & Russia \\
\hline 16 & $\mathrm{P} 4$ & 1983 & Carp & Russia \\
\hline 17 & KKK & 1986 & Carp & Russia \\
\hline 18 & 1.4 & 1993 & Carp & Russia \\
\hline 19 & Ud & 1994 & Carp & Russia \\
\hline 20 & No. 3 & 1986 & Grass carp & Ukraine (Shchelkunov \& Shchelkunova 1989) \\
\hline 21 & $1 / 99$ & 1999 & Carp & Ukraine \\
\hline 22 & M2 & 1983 & Silver carp & Moldova \\
\hline 23 & $2 / 90$ & 1990 & Carp & Moldova \\
\hline 24 & 500 & 1996 & Carp & Czech Republic \\
\hline 25 & 539 & 1997 & Carp & Czech Republic \\
\hline 26 & 541 & 1998 & nd & Czech Republic \\
\hline 27 & 613 & 1999 & Carp & Czech Republic \\
\hline 28 & 555 & 1999 & Carp & Czech Republic \\
\hline 29 & 556 & 1999 & Carp & Czech Republic \\
\hline 30 & 551 & 1999 & Carp & Czech Republic \\
\hline 31 & 552 & 1999 & Carp & Czech Republic \\
\hline 32 & 590 & 1999 & Pike & Czech Republic \\
\hline 33 & 609 & 2001 & Carp & Czech Republic \\
\hline 34 & 612 & 2002 & Carp & Czech Republic \\
\hline
\end{tabular}

$6 \mu$ of the extracted RNA, 20 pmol of each of the external primers, $0.2 \mathrm{mM}$ of each of the $4 \mathrm{dNTP}, 5.0 \mathrm{mM}$ of dithiothreitol, $40 \mathrm{U}$ of RNase inhibitor (Promega), 1 RT-PCR buffer (with $1.5 \mathrm{mM} \mathrm{MgCl}$ ), $1 \mu$ l of enzyme mix (Boehringer Mannheim) and RNase-free water up to the final volume. RT $\left(30 \mathrm{~min}\right.$ at $50^{\circ} \mathrm{C}$ and $2 \mathrm{~min} 30 \mathrm{~s}$ at $94^{\circ} \mathrm{C}$ ) was followed by 34 amplification cycles of $30 \mathrm{~s}$ at $94^{\circ} \mathrm{C}$, $1 \mathrm{~min}$ at $50^{\circ} \mathrm{C}$, and $1 \mathrm{~min}$ at $68^{\circ} \mathrm{C}$, and a final holding step for $7 \mathrm{~min}$ at $68^{\circ} \mathrm{C}$.

Nested PCR. The PCR reaction mixture contained $2 \mu \mathrm{l}$ of the amplification product obtained by RT-PCR, $50 \mathrm{pmol}$ of each of the internal primers, $0.1 \mathrm{mM}$ of each of the $4 \mathrm{dNTP}, 1$ PCR buffer (with $1.5 \mathrm{mM} \mathrm{MgCl}_{2}$ ), 2.5 U of DyNAzyme II DNA Polymerase (Finnzymes), in a final volume of $100 \mu \mathrm{l}$. PCR was performed in 25 cycles of $30 \mathrm{~s}$ at $94^{\circ} \mathrm{C}, 30 \mathrm{~s}$ at $55^{\circ} \mathrm{C}$, and $30 \mathrm{~s}$ at $72^{\circ} \mathrm{C}$, and finished by holding at $72^{\circ} \mathrm{C}$ for $7 \mathrm{~min}$. RT-PCR and nested
PCR were run in a Mastercycler Gradient thermal cycler. The amplified PCR products were analysed for purity and size by electrophoresis in $2 \%$ agarose gels stained with ethidium bromide. DNA molecular weight standards, DNA Ladder VIII (Boehringer Mannheim) and $1 \mathrm{~Kb}$ Plus DNA Ladder (Gibco BRL, Life Technologies), were used to determine the size of the RT-PCR and nested PCR products, respectively.

Specificity of PCR. The specificity of the primers for the demonstration of SVCV in infected cell cultures was checked using 5 of the 7 PFRV strains described by Jørgensen et al. (1989) (except PFRV Strains V 76 and S 64), Strain F1 of viral haemorrhagic septicaemia virus (VHSV), Strain OSV of infectious haematopoietic necrosis virus (IHNV), and Strains Ab, Sp, and VR-299 of infectious pancreatic necrosis birnavirus (IPNV). 
Sensitivity of PCR. The sensitivity of the PCR was tested using a 10-fold dilution series of RNA extracted from Isolates 21 or 25 grown in EPC culture (titre of $10^{5.8}$ and $10^{8.2} \mathrm{TCID}_{50} \mathrm{ml}^{-1}$, respectively). The virus titres were calculated by the method of Reed \& Münch (1938).

DNA sequencing and sequence analysis. PCR products from cultivated cell-culture isolates (Czech Isolates 24, 27, 28, 29, Hungarian Isolates 8, 9, and Isolate 5 of unknown origin) were sequenced. The sequencing was preceded by purification of the DNA sample using the QIAquick System (Qiagen) according to the manufacturer's instructions. Sequencing was performed using both external primers and the dideoxynucleotide chain termination method (ABI PRISM BigDye v2.0 Terminator Cycle Sequencing Kit, Performance Optimized Polymer 6 [Applied Biosystems]) to confirm the sequences on both DNA strands. Nucleotide and predicted amino acid sequences of PCR products of 7 isolates were compared with the sequence of the reference strain Fijan (Sequence A submitted to GenBank by H. V. Bjørklund in 1994, Accession No. U18101 and Sequence B submitted to GenBank by M. T. Rossius in 1994, Accession No. Z37505) (Bjørklund et al. 1996). GeneCompar (Applied Maths, version 2) software was used to obtain sequence alignments.

\section{RESULTS}

\section{PCR}

Effective and specific amplification of viral nucleic acid was preceded by optimisation of PCR conditions. Primer annealing temperatures were the most critical variables. The optimum annealing temperatures for specific DNA fragments in RT-PCR and nested PCR were 50 and $55^{\circ} \mathrm{C}$, respectively (data not shown).

A

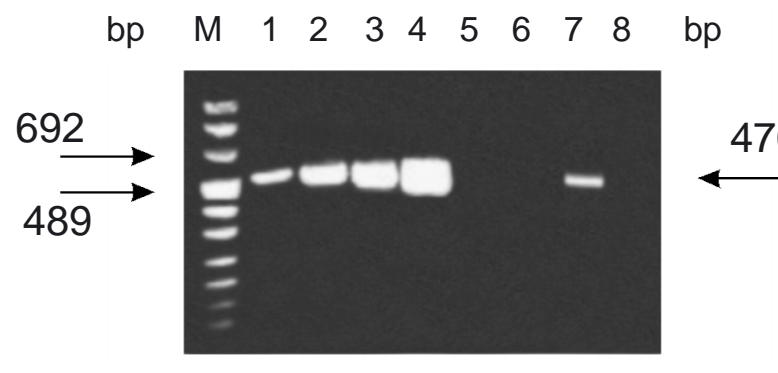

\section{Specificity of PCR}

As expected, the 470 bp DNA product was amplified by RT-PCR from RNA of the Fijan strain and from all the SVCV isolates studied (Fig. 1A, Lanes 1 to 4). Similarly, the expected $141 \mathrm{bp}$ DNA product was synthesised by nested PCR (Fig. 1B, Lanes 1 to 4). No DNA was amplified from PFRV (Fig. 1A,B, Lane 5), VHSV, IHNV, IPNV (data not shown), EPC (Fig. 1A,B, Lane 6) or FHM (data not shown) cells. Sequences of RT-PCR products confirmed their identity and that they were derived from the virus genome. The high concentration of the RT-PCR product used as a template in the nested PCR generated additional PCR products. Diluted templates produced only specific PCR products.

\section{Sensitivity of PCR}

The sensitivity of PCR in demonstrating SVCV in cell cultures (Isolates 21 or 25) was tested in a 10-fold dilution series of extracted RNA. RT-PCR yielded a specific $470 \mathrm{bp}$ product at $10^{-0.1} \mathrm{TCID}_{50} \mathrm{ml}^{-1}$ (data not shown) or $10^{1.3} \mathrm{TCID}_{50} \mathrm{ml}^{-1}$ (Fig. 2A), the $141 \mathrm{bp}$ product resulting from nested PCR was detectable in agarose gels at $10^{-1.1} \mathrm{TCID}_{50} \mathrm{ml}^{-1}$ (data not shown) or $10^{-0.7}$ $\mathrm{TCID}_{50} \mathrm{ml}^{-1}$ (Fig. 2B) for the respective isolates.

\section{Virus detection in tissue homogenates}

Amplification of tissue homogenates infected with Isolates 24 (Fig. 1A,B: Lane 7), 25, 30, 33 and 34 (data not shown) yielded the specific DNA product in the primary RT-PCR, but nested PCR was necessary to demonstrate it in tissue homogenate infected with Isolate 32 (Fig. $1 \mathrm{~A}, \mathrm{~B}$, Lane 8), and in samples experimentally infected with Isolates 24 or 27 (data not shown). No PCR product was obtained from tissue homogenates prepared from SVCV-negative field samples (data not shown).

\section{B}

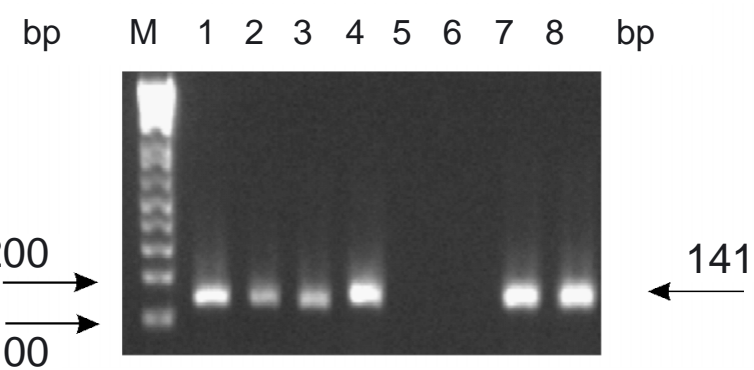

Fig. 1. Spring viraemia of carp virus (SVCV). Products of RT-PCR and nested PCR. (A) RT-PCR amplification of RNA template of SVCV Fijan strain (Lane 1) and Isolates 12 (Lane 2), 10 (Lane 3), 28 (Lane 4); Lane 5: PFRV Strain 332; Lane 6: non-infected EPC cells; Lanes 7 and 8: tissue homogenates infected with SVCV Isolates 24 (Lane 7) and 32 (Lane 8). (B) Nested PCR amplification of PCR products in (A). M: molecular marker 
A

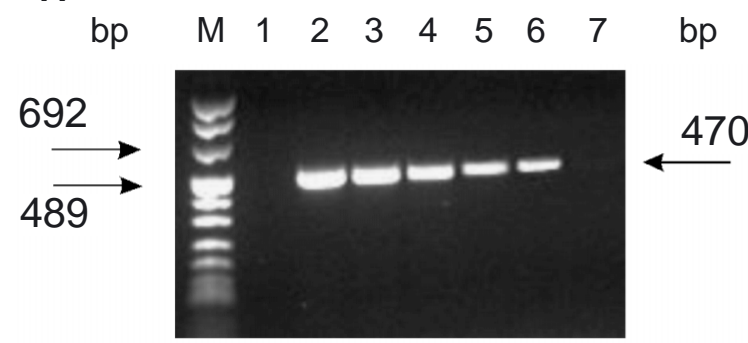

B

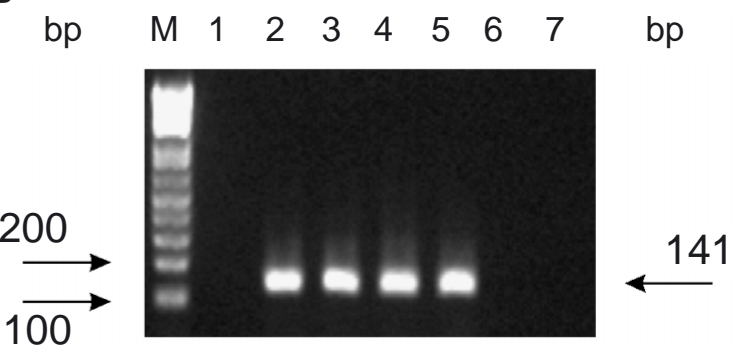

Fig. 2. Spring viraemia of carp virus (SVCV). Sensitivity of RT-PCR and nested PCR. (A) Lane 1: without template; Lanes 2 to 7 : RT-PCR products corresponding to template titres $\left(\right.$ TCID $_{50} \mathrm{ml}^{-1}$ ) of Isolate 25 of $10^{5.3}$ (Lane 2$), 10^{4.3}$ (Lane 3 ), $10^{3.3}$ (Lane 4$), 10^{2.3}$ (Lane 5), $10^{1.3}$ (Lane 6), and $10^{0.3}$ (Lane 7). (B) Lane 1: without template; Lanes 2 to 7: nested PCR products corresponding to tem-

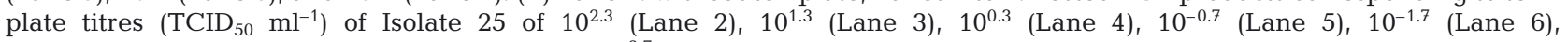
and $10^{-2.7}$ (Lane 7 ). M: molecular marker

\section{Sequence analysis}

Analysis of PCR products showed low nucleotide variability in the sequenced region of the SVCV G gene. The 426 nucleotides of 7 SVCV isolates deposited in GenBank (Accession Nos. AY196199-205) and the Fijan strain (Sequence A, Accession No. U18101 and Sequence B, Accession No. Z37505) (Bjørklund et al. 1996) were characterised by at least $97.4 \%$ similarity. The highest variability (97.4 to $98.1 \%$ nucleotide similarities) within this group was observed between the Hungarian and the other isolates (Table 2).

In each of the sequenced isolates, a few nucleotide substitutions were observed and at least 1 of the substitutions was non-conservative for each isolate compared with Sequence A of the Fijan strain (Accession No. U18101) (Bjørklund et al. 1996). Compared with Sequence B of the Fijan strain (Accession No. Z37505), all nucleotide substitutions were conservative in Isolate 9 only (data not shown).

A comparison of predicted amino acid sequences of the SVCV isolates with Sequence B of the Fijan strain
(Accession No. Z37505) revealed 3 amino acid exchanges: val ${ }^{290}$ ile in Isolates 24, 27, and 28; asp ${ }^{376}$ glu in Isolate 24; and $\mathrm{asn}^{413}$ asp in Czech Isolates 24, 27, and 29, Hungarian Isolate 8 and Isolate 5. Besides these exchanges, the exchange $\arg ^{350}$ lys was found in all sequenced isolates compared with Sequence A of the Fijan strain (Accession No. U18101) (data not shown).

\section{DISCUSSION}

SVC is one of the transmissible diseases of farmed fishes that cause considerable economic losses. No vaccine against SVC is available, and the only protection is prompt identification and elimination of infected individuals. Therefore, rapid diagnosis is essential for the timely implementation of effective measures.

The diagnostic methods currently used, including virus neutralisation and immunofluorescence tests and ELISA preceded by virus propagation in cell cultures, are laborious and time-consuming. The critical step is

Table 2. Spring viraemia of carp rhabdovirus (SVCV). Similarity matrix of glycoprotein gene region of SVCV Fijan strain Sequence A (1) and Sequence B (3) and Isolates 29 (2), 5 (4), 8 (5), 9 (6), 28 (7), 24 (8) and 27 (9). Comparison is presented as percentage nucleotide similarities. Pairwise alignments were created by the neighbour-joining method using GeneCompar software, version 2 (Applied Maths). A and B sequences of Fijan strain have been described by Bjørklund et al. (1996; Accession No. U18101) and M. T. Rossius, 1994 (unpubl. data; Accession No. Z 37505), respectively

\begin{tabular}{|c|c|c|c|c|c|c|c|c|c|c|}
\hline \multicolumn{2}{|c|}{ Isolate } & \multirow{3}{*}{$\begin{array}{c}1 \\
100\end{array}$} & \multirow{3}{*}{2} & \multirow{3}{*}{3} & \multirow[b]{2}{*}{4} & \multicolumn{2}{|c|}{ — Isolate } & \multirow[b]{2}{*}{7} & \multirow[b]{2}{*}{8} & \multirow[b]{2}{*}{9} \\
\hline & & & & & & 5 & 6 & & & \\
\hline 1 & Fijan-A & & & & & & & & & \\
\hline 2 & 29 & 99.3 & 100 & & & & & & & \\
\hline 3 & Fijan-B & 99.3 & 99.1 & 100 & & & & & & \\
\hline 4 & 5 & 98.8 & 99.1 & 99.5 & 100 & & & & & \\
\hline 5 & 8 & 97.9 & 98.1 & 98.6 & 98.6 & 100 & & & & \\
\hline 6 & 9 & 97.9 & 97.7 & 98.6 & 98.1 & 99.5 & 100 & & & \\
\hline 7 & 28 & 99.3 & 99.5 & 99.1 & 98.6 & 97.7 & 97.7 & 100 & & \\
\hline 8 & 24 & 98.8 & 99.5 & 98.8 & 98.8 & 97.9 & 97.4 & 99.5 & 100 & \\
\hline 9 & 27 & 99.1 & 99.8 & 98.8 & 98.8 & 97.9 & 97.4 & 99.8 & 99.8 & 100 \\
\hline
\end{tabular}


virus propagation, which can fail for reasons such as too small an amount of infectious virus particles, virus inactivation, or toxicity of the test material for cell cultures. Modified versions of the immunofluorescence test and ELISA for direct demonstration of SVCV in clinical samples are more rapid, but yield only preliminary results which must be confirmed by virus isolation in cell cultures.

An alternative to conventional diagnostic procedures is the identification of specific nucleic acids. Oreshkova et al. (1999) detected SVCV in cell cultures and fish tissues using a biotinylated probe hybridising genes encoding glycoprotein or membrane protein of SVCV. However, the detection of SVCV in fish tissues by nucleotide analysis of the $\mathrm{G}$ gene region does not seem to be more sensitive and specific than by ELISA (Way 1991, Rodák et al. 1993); moreover, non-specific reactions were often observed in experiments with the G probe. Ahne et al. (1998) used the ribonuclease protection assay (RPA) based on full-length $\mathrm{G}$ to differentiate SVCV from PFRV. The drawbacks of the RPA technique include probe instability, radioactive hazard, and the necessity for virus propagation. Moreover, hybridisation techniques are laborious and therefore unsuitable for routine diagnostics. PCR was successfully used in the diagnosis of rhabdovirus infections of salmonid fishes (Bruchhof et al. 1995, Miller et al. 1998, Strommen \& Stone 1998, Guillou et al. 1999). There are no data in the available literature on RT-PCR use in the direct diagnosis of SVC, although the RT-PCR protocol has been used for the non-specific identification of SVCV on the basis of sequence data (Rowley et al. 2001).

Bjørklund et al. (1996) compared G amino-acid sequences of 13 species of the family Rhabdoviridae. SVCV represented by the Fijan strain showed maximum $(53.3 \%)$ similarity with the vesicular stomatitis New Jersey virus and minimum (40.5\%) similarity with IHNV. The structural SVCV G gene showed 45.5 to $45.7 \%$ similarity with that of VHSV. Similar data have been reported by other authors from phylogenetic analyses of the $\mathrm{G}$ gene of various rhabdovirus species (Wang \& Walker 1993, Morzunov et al. 1995).

The sequences of the primers used in PCR to identify SVCV were derived from the G gene, which shows considerable heterogeneity among rhabdovirus species (Wang \& Walker 1993, Morzunov et al. 1995, Bjørklund et al. 1996). Only sequences of the $\mathrm{G}$ gene of the Fijan strain of SVCV were available from the GenBank (Accession Nos. U18101 and Z37505); therefore the primers could not be precisely identified with the conservative gene regions. However, the primers allowed us to specifically identify the reference Fijan strain and all the tested SVCV isolates and thereby to differentiate these from the IPNV birnavirus and from other fish rhabdoviruses, including the closely related PFRV vesiculovirus. This result corroborates the suitability of the design of our primers and the applicability of the method to the diagnosis of SVCV infections. Moreover, the PCR described here allowed the demonstration of virus in cell-culture systems at titres significantly lower than those used in the diagnostic ELISA method (Rodák et al. 1993). PCR sensitivity was independently assessed in 2 isolates (Czech and Ukrainian), and the sensitivity values were comparable $\left(\sim 10^{-1}\right.$ $\left.\mathrm{TCID}_{50} \mathrm{ml}^{-1}\right)$. The probable reason for this high sensitivity is that PCR also detects separate fragments of viral nucleic acid, whereas intact infectious virus particles are necessary for isolation. The sensitivity of PCR in tissue homogenates has not been evaluated, and the diagnostic application of this method using homogenates must be preceded by testing a larger number of field tissue samples and comparing PCR results with those of other diagnostic methods.

RT-PCR identified SVCV reliably in cell cultures, but was inadequate for virus identification in fish tissues. Amplification of a specific product by RT-PCR was observed in 5 of the 8 positive tissue samples tested, whereas the subsequent nested PCR allowed virus identification in all infected clinical samples.

Although the nucleotide analysis demonstrated high similarity of the sequenced region of SVCV G gene, 2 amino acid substitutions were most frequently observed in the alignment of predicted glycoprotein sequences. The substitution asn ${ }^{413}$ asp was found in $5 \mathrm{SVCV}$ isolates and the $\mathrm{val}^{290}$ ile substitution was found in 3 Czech isolates.

Alignment of predicted amino acid sequences revealed the identity of Isolate 9 and the $B$ sequence of the Fijan strain (Accession No. Z37505), as well as the identity of Isolates 5, 8, and 29, although some nucleotide substitutions were observed. While substitutions of nucleotides of Isolate 9 were conservative in comparison with the $B$ sequence of the Fijan strain, substitutions of nucleotides in Isolates 5,8 , and 29 resulted in identical exchange of amino acids $\operatorname{asn}^{413}$ asp.

Nucleotide analysis of the $G$ gene region of the SVCV isolates sequenced so far in our laboratory indicates a close genetic relationship among isolates from the same sampling sites. This finding must be tested in further analyses of relationships among other SVCV isolates.

It can be concluded that PCR is suitable for the demonstration of SVCV in cell cultures. Using PCR, we also identified SVCV in all the positive fish-tissue samples examined. For SVCV detection in tissue samples, nested PCR is particularly important in increasing the sensitivity of the method. Moreover, unlike serological methods, PCR allows differentiation between the 
vesiculoviruses SVCV and PFRV and considerably shortens the time necessary for virus identification. For diagnostic purposes, it will be necessary to test the PCR on greater numbers of tissue samples, but it can be used as a confirmatory method for determining SVCV in cell cultures.

Acknowledgements. The authors are grateful to I. Halíková and L. Leharová for technical assistance and V. Valentová for her comments on the manuscript. Virus strains and SVCV isolates (except the Czech Isolates) used in this study were kindly provided by Dr. N. Lorenzen of the Danish Veterinary Laboratory, Denmark and Dr. I. Shchelkunov of the All-Russian Research Institute of Freahwater Fisheries, Russia. This work was supported by the European community (EC Project FAIR CT-98-4064) and the National Agency for Agricultural Research (NAZV) under grant EP-9187.

\section{LITERATURE CITED}

Ahne W (1986) Unterschiedliche biologische Eigenschaften. 4. Cyprinidenpathogener Rhabdovirusisolate. J Vet Med Ser B 33:253-259

Ahne W, Kurath G, Winton JR (1998) A ribonuclease protection assay can distinguish spring viremia of carp virus from pike fry rhabdovirus. Bull Eur Assoc Fish Pathol 18:220-224

Amos KH (1985) Procedures for the detection and identification of certain fish pathogens, 3rd edn. Fish Health Section, American Fisheries Society, Bethesda, MD

Bjørklund HV, Higman KH, Kurath G (1996) The glycoprotein genes and gene junctions of the fish rhabdoviruses spring viremia of carp virus and hirame rhabdovirus: analysis of relationships with other rhabdoviruses. Virus Res 42: $65-80$

Bruchhof B, Marquardt O, Enzmann PJ (1995) Differential diagnosis of fish pathogenic rhabdoviruses by reverse transcriptase-dependent polymerase chain reaction. J Virol Methods 55:111-119

Coll JM (1995) The glycoprotein G of rhabdoviruses. Arch Virol 140:827-851

Fijan N, Petrinec Z, Sulimanovič D, Zwillenberg LO (1971) Isolation of the viral causative agent from the acute form of infectious dropsy of carp. Vet Arh 41:125-138

Fijan N, Matašin Z, Jeney Z, Oláh J, Zwillenberg LO (1984) Isolation of Rhabdovirus carpio from sheatfish (Silurus glanis) fry. In: Olah J (ed) Fish, pathogens and enviroment in European polyculture. Akademiai Kiado, Budapest, p 17-24

Guillou JP, Merle G, Henault S, Hattenberger AM (1999) Detection of viral haemorrhagic septicaemia virus (VHSV) by reverse transcription polymerase chain reaction: a step towards diagnostic validation. Vet Res 30:49-60 (in French with English Abstract)

Jørgensen PEV, Olesen NJ, Ahne W, Lorenzen N (1989) SVCV and PFR viruses: serological examination of 22 isolates indicates close relationship between the two fish rhabdoviruses. In: Ahne W (ed) Viruses of lower vertebrates. Springer-Verlag, Berlin, p 349-366

Editorial responsibility: Carey Cunningham, Aberdeen, Scotland
Karunasagar I, Karunasagar I (1999) Diagnosis, treatment and prevention of microbial diseases of fish and shellfish. Curr Sci 76:387-399

Miller TA, Rapp J, Wastlhuber U, Hoffmann RW, Enzmann PJ (1998) Rapid and sensitive reverse transcriptase-polymerase chain reaction based detection and differential diagnosis of fish pathogenic rhabdoviruses in organ samples and cultured cells. Dis Aquat Org 34:13-20

Morzunov SP, Winton JR, Nichol ST (1995) The complete genome structure and phylogenetic relationship of infectious hematopoietic necrosis virus. Virus Res 38:175-192

Office International des Epizooties (2000) Diagnostic manual for aquatic animal diseases, 3rd edn. Office International des Epizooties, Paris

Oreshkova SF, Shchelkunov IS, Tikunova NV, Shchelkunova TI, Puzyrev AT, Ilyichev AA (1999) Detection of spring viremia of carp virus isolates by hybridization with nonradioactive probes and amplification by polymerase chain reaction. Virus Res 63:3-10

Reed RJ, Münch H (1938) A simple method of estimating fifty per cent endpoints. Am J Hyg 27:493-497

Rodák L, Pospíšil Z, Tománek J, Veselý T, Obr T, Valíček L (1993) Enzyme-linked immunosorbent assay (ELISA) for the detection of spring viraemia of carp virus (SVCV) in tissue homogenates of the carp, Cyprinus carpio. J Fish Dis 16:101-111

Rowley H, Graham DA, Campbell S, Way K, Stone DM, Curran WL, Bryson DG (2001) Isolation and characterisation of rhabdovirus from wild common bream Abramis brama, roach Rutilus rutilus, farmed brown trout Salmo trutta and rainbow trout Oncorhynchus mykiss in Northern Ireland. Dis Aquat Org 48:7-15

Roy P, Clewley JP (1978) Spring viremia of carp virus RNA and virion-associated transcriptase activity. J Virol 25: 912-916

Shchelkunov IS, Shchelkunova TI (1989) Rhabdovirus carpio in herbivorous fishes: isolation, pathology and comparative susceptibility of fishes. In: Ahne W (ed) Viruses of lower vertebrates. Springer-Verlag, Berlin, p 333-348

Strommen HK, Stone DM (1998) Detection of viral haemorrhagic septicaemia (VHS) virus in fish tissues by seminested polymerase chain reaction (PCR). In: Barnes AC, Davidson GA, Hiney MP, McIntosh D (eds) Methodology in fish diseases research. Fisheries Research Services, Aberdeen

Sundsfjørd A, Olsvik O (1997) Nucleic acid amplification techniques in detection and diagnosis of medically important viral infections. In: Lee HH (ed) Nucleic acid amplification technologies: application to disease diagnosis. Birkhauser Boston, Cambridge, MA, p 183-199

Wang Y, Walker PJ (1993) Adelaide river rhabdovirus expresses consecutive glycoprotein genes as polycistronic mRNAs: new evidence of gene duplication as an evolutionary process. Virology 195:719-731

Wolf K (1988) Fish viruses and fish viral diseases. Cornell University Press, Ithaca, NY

Wunner WH, Peters D (1991) Family Rhabdoviridae. Arch Virol Suppl 2:250-262

Way K (1991) Rapid detection of SVC virus antigen in infected cell cultures and clinically diseased carp by the enzymelinked immunosorbent assay (ELISA). J Appl Ichthyol 7: 95-107

Submitted: March 5, 2002; Accepted: March 26, 2003

Proofs received from author(s): July 14, 2003 